\title{
Isolation By Distance (IBD) signals in the deep-water rose shrimp Parapenaeus longirostris (Lucas, 1846) (Decapoda, Panaeidae) in the Mediterranean Sea
}

\author{
S. Lo Brutto*, T. Maggio, M. Arculeo \\ Dept. STEBICEF, University of Palermo, Via Archirafi 18, 90123 Palermo, Italy
}

\section{A R T I C L E I N F O}

\section{Article history:}

Received 6 February 2013

Received in revised form

6 May 2013

Accepted 11 May 2013

\section{Keywords:}

Parapenaeus longirostris

AFLP

mtDNA

Isolation By Distance

Mediterranean Sea

\begin{abstract}
A B S T R A C T
The identification of boundaries of genetic demes is one of the major goals for fishery management, and few Mediterranean commercial species have not been studied from a genetic point of view yet. The deepwater rose shrimp Parapenaeus longirostris (Lucas, 1846) is one of the most important components of commercial landings in Mediterranean, its fishery aspects have received much attention, regrettably without any concern for the genetic architecture of its populations. The population structure in the central and eastern Mediterranean Sea (captures from six Italian and two Greek landings) has been analysed on the basis of surveys carried out with mitochondrial and AFLP markers. Data revealed the presence of a gradual discrepancy along a west-east axis. This species, occurring mainly at a depth of between 100 and $400 \mathrm{~m}$, is not strongly confined in isolated demes, but it demonstrates an 'Isolation By Distance' model, within the Mediterranean Sea, which includes geographical areas with a some degree of isolation. The role of hydrodynamic forces, such as currents, water fronts, is discussed; and a further evidence of the 'Levantine isolation' within Mediterranean basin is shown.
\end{abstract}

(c) 2013 Elsevier Ltd. All rights reserved.

\section{Introduction}

The deep-water rose shrimp, Parapenaeus longirostris (Lucas, 1846) is an epibenthic, natantian shrimp with thermophilic behaviour, a preferential range of $14-15^{\circ} \mathrm{C}$ (Ungaro and Gramolini, 2006), a rapid growth rate and a wide geographic distribution from the Western Atlantic Ocean throughout the entire Mediterranean Sea (Sobrino et al., 2005). In the latter, the species inhabits sandymuddy bottoms (Nouar and Maurin, 2001) and its bathymetric distribution ranges from between $50 \mathrm{~m}$ and $750 \mathrm{~m}$ although its maximum abundance has been observed between depths of 100 and $500 \mathrm{~m}$ (Holthius, 1980; Tom et al., 1988; Lembo et al., 1999; Abelló et al., 2002). P. longirostris shows a marked size-dependent distribution along depth, with small individuals being found at the edge of the continental shelf and larger specimens distributed at greater depths (Froglia, 1982; Ardizzone et al., 1990; Lembo et al., 1999; Abelló et al., 2002; Bilgin et al., 2009; Guijarro et al., 2009). Both sexes reach maturity in the first year of life (Froglia, 1982) and adults move during the spawning period to shallower waters where planktonic larvae have been found. After spawning, the post

\footnotetext{
* Corresponding author.

E-mail address: sabrina.lobrutto@unipa.it (S. Lo Brutto).
}

larva reaches the sandy-muddy bottoms on the continental shelf and begins a bentho-pelagic cycle (Heldt, 1938; Tom et al., 1988; Dos Santos, 1998). P. longirostris does not have a single reproductive peak, as found in shrimps occurring at greater depths (like Aristeus antennatus), and maturing females can be found all year round in the Mediterranean waters (Bayhan et al., 2005; Dereli and Erdem, 2011; Nouar et al., 2011).

Whilst natantian and a feeder of zooplankton (Nouar et al., 2011), $P$. longirostris is a eurybathic species, having a tight relationship with the sea bottom (Colloca et al., 2004). Indeed, it can be considered as an active, carnivorous predator of bathypelagic, benthic and endobenthic preys (Kapiris, 2004), displaying a secondary activity of scavenging, which is commonly attributed to reptantian decapods, (Cartes, 1995).

$P$. longirostris is one of the most important fishery resources of the epibathyal grounds along Mediterranean coasts, and recent FAO statistics regarding landings have reported it as the fifth species among crustaceans. It is also the target species for the Italian, Spanish and French bottom trawl (FAO FishStat plus vers 2.3 http:// www.fao.org/fishery/statistics/software/fishstat/en). The exploitation of this species takes place all year round, even if peak landings occur from March to July (Levi et al., 1995; Abdel Razek et al., 2006). Studies regarding the deep-water rose shrimp have primarily focused on its distribution, biology (Bombace, 1975; Lembo et al., 
2000; Mori et al., 2000; Abelló et al., 2002; Bayhan et al., 2005; Arculeo, 2009), and fishery aspects (Sbrana et al., 2003; Sobrino et al., 2005; Sbrana et al., 2006; Ligas et al., 2011; Aydın and Tosunoğlu, 2012). The population dynamics has been studied, in particular regarding the link between population abundance and environmental factors (Guijarro et al., 2009; Ligas et al., 2011). Unfortunately, there is a paucity of studies investigating the genetic population structure of $P$. longirostris, although such an integrative approach would be a helpful tool in understanding the effects of environmental changes on the species.

Recently, García-Merchán et al. (2012) analyzed a partial region of the mitochondrial cytochrome oxidase subunit I (COI) of seven decapod species, among which four samples of $P$. longirostris, collected at both sides of the oceanographic discontinuity area separating Atlantic and Mediterranean. Their results did not score a genetic break within $P$. longirostris, highlighting that the effect of the fronts, placed in the Gibraltar Strait area, though barriers to gene flow for several species, cannot be generalized for all the decapods. García-Merchán et al. (2012) proposed that deeper is the decapod species lower is the genetic structure detected, being less affected by oceanographic processes occurring in the upper layers. However, they argued that the relatively low number of species studied recommends further studies and that the results could be due to the characteristics of the single molecular marker used.

The paper by García-Merchán et al. is a good example of how genetic approach can be a helpful tool in understanding the effects of environmental variables within a species.

As a matter of fact, studies regarding the genetic population analysis of other Mediterranean decapods (A. antennatus in Maggio et al. (2009a); Lo Brutto et al., 2012; Melicertus (Penaeus) kerathurus in Pellerito et al. (2009); Nephrops norvegicus in Stamatis et al. (2006)) describes patterns explained by three causes acting solely or in combination: (i) the effect of oceanographic features such as currents, water fronts, physical barriers; (ii) features relating to life history, such as larval dispersal or adult displacement ability; and (iii) the role of geographical distance on gene flow (Isolation By Distance, IBD). Generally, the genetic architecture depicted by Mediterranean decapods reveals species-specific patterns (GarcíaMerchán et al., 2012), which make it difficult to design management actions suitable for commercial species.

The aim of this Paper is to assess the genetic population structure of $P$. longirostris, employing nuclear (Amplified Fragment Length Polimorphism, AFLP) and mitochondrial (Control Region sequences) markers to assess whether distinct stocks occur in the Mediterranean Sea. The comparison of these two markers enable us to make a more comprehensive investigation into genetic diversity; specifically, highly resolving DNA fingerprinting techniques (such as AFLP markers and mtDNA control regions) have proven to be valuable in estimating genetic diversity in natural populations (Lo Brutto et al., 2012; GarcíaMerchán et al., 2012).

\section{Methods}

\subsection{Sampling}

Samples of $P$. longirostris from the Mediterranean Sea were collected from the Tyrrhenian sub-basin (TYR1, TYR2 and TYR3), the Strait of Sicily (SS1 and SS2), Adriatic Sea (AD1) and from the Aegean Sea (AEG1 and AEG2) (Table 1 and Fig. 1 for details). Genomic DNA was extracted from $20 \mathrm{mg}$ of ethanol-preserved pleopods accordingly to the protocol of the DNeasy Tissue Kit (Qiagen).
Table 1

Samples sites of Parapenaeus longirostris, analyzed with AFLP and mtDNA.

\begin{tabular}{llllll}
\hline & Location of landings & $\begin{array}{l}\text { Mediterranean } \\
\text { sub-basin }\end{array}$ & $\begin{array}{l}\text { Sample } \\
\text { code }\end{array}$ & $\begin{array}{l}N \\
\text { AFLP }\end{array}$ & $\begin{array}{l}N \\
\text { mtDNA }\end{array}$ \\
\hline 1 & $\begin{array}{l}\text { Porto S. Stefano } \\
\text { (Tuscany, Italy) }\end{array}$ & Tyrrhenian Sea & TYR1 & 40 & 14 \\
2 & Terrasini (north Sicily, Italy) & & TYR2 & 22 & 17 \\
3 & Porticello (north Sicily, Italy) & & TYR3 & 22 & 15 \\
4 & Scoglitti (south Sicily, Italy) & Strait of Sicily & SS1 & 30 & 17 \\
5 & Porto Palo (south Sicily, Italy) & & SS2 & 30 & 14 \\
6 & Fano (The Marches, Italy) & Adriatic Sea & AD1 & 24 & 15 \\
7 & Crete (Greece) & Aegean Sea & AEG1 & 24 & 6 \\
8 & Kavala (Greece) & & AEG2 & 48 & 9 \\
\hline
\end{tabular}

$N$, sample size.

\subsection{AFLP analysis}

The AFLP analysis was performed in accordance with the description by Vos et al. (1995). Restriction digests were carried out in $40 \mu \mathrm{l}$ reactions, using $200 \mathrm{ng}$ of genomic DNA, 5 U Taq I, 5U EcoRI, $1 \times$ buffer RL ( $50 \mathrm{mM}$ TrisHAc, $50 \mathrm{mM} \mathrm{MgCl}_{2}, 250 \mathrm{mM}$ KAc, $25 \mathrm{mM}$ DTT, $25 \mathrm{ng} / \mu \mathrm{l} \mathrm{BSA}$ ) for $1 \mathrm{~h}$ at $65^{\circ} \mathrm{C}$ and $1 \mathrm{~h}$ at $37^{\circ} \mathrm{C}$. Diluted ligation product was used as template for a pre-selective amplification. The successive selective PCR was performed by using the pre-selective PCR products. Twelve primer pairs were analysed and five selective primer combinations were chosen to generate all AFLP profiles: EcoRI-AAA + TaqI-AGG, EcoRI-AAA + TaqI-ATG, EcoRI-AAA + TaqIACA, EcoRI-ATT + TaqI-AGG and EcoRI-ATT + TaqI-ATG. Selective PCR products were separated on an ABI PRISM 310 automated sequencer (Applied Biosystem) with a GeneScan Rox 500 standard internal size. Electropherograms were subsequently analysed using Genescan 2.02 and Genotyper 2.5 (Applied Biosystems).

The percentage of polymorphic loci (5\% level) and unbiased estimates of genetic diversity were computed using AfLP-Surv 1.0 software with a non-uniform prior distribution of allele frequencies (Vekemans et al., 2002). Allelic frequencies at AFLP loci were calculated from the observed frequencies of the fragments using the Bayesian approach, as proposed by Zhivotovsky (1999) for diploid species. Statistics relating to gene diversity were computed, using Aflp-Surv 1.0 software, strictly following the treatment proposed by Lynch and Milligan (1994); total gene diversity $H_{\mathrm{T}}(\mathrm{Nei}$, 1987) was calculated by pooling all individuals into a single metapopulation. $H_{\mathrm{E}}$, within-population Nei's gene diversity (Nei, 1987), was also computed.

An identification of outlier loci was carried out in accordance with the approaches of Beaumont and Nichols (1996) and Beaumont and Balding (2004), as implemented by the DFDIST software (http://www.rubic.rdg.ac.uk), following the procedure modified by Caballero et al. (2008). The procedure of identifying outlier loci is based on the assumption that loci under selection exhibit higher or lower $F_{\mathrm{ST}}$ values than the majority of neutral loci. $F_{\mathrm{ST}}$ is an estimate of genetic differentiation among subpopulations related to gene flow. DFDIST initially calculates empirical $F_{\mathrm{ST}}$ values for each locus and, from the empirical distribution, the trimmed mean $F_{\mathrm{ST}}$ is determined by removing the highest and lowest $30 \%$ observed in the empirical dataset. The software performs a coalescent simulation (50,000 realizations) to generate data sets with a mean $F_{\mathrm{ST}}$, which equals the trimmed mean $F_{\mathrm{ST}}$, to obtain significant values which are higher or lower than the quantile limits (5\%,50\% and $95 \%)$. Four loci with higher or lower $F_{\mathrm{ST}}$ values were considered under directional and balancing selection respectively, and, as outliers, excluded from the subsequent analysis.

Population differentiation was assessed by a hierarchical Analysis of MOlecular VAriance (AMOVA), using ARLEQUIN 3.0 (Excoffier et al., 2005), clustering the samples in different ways according to 

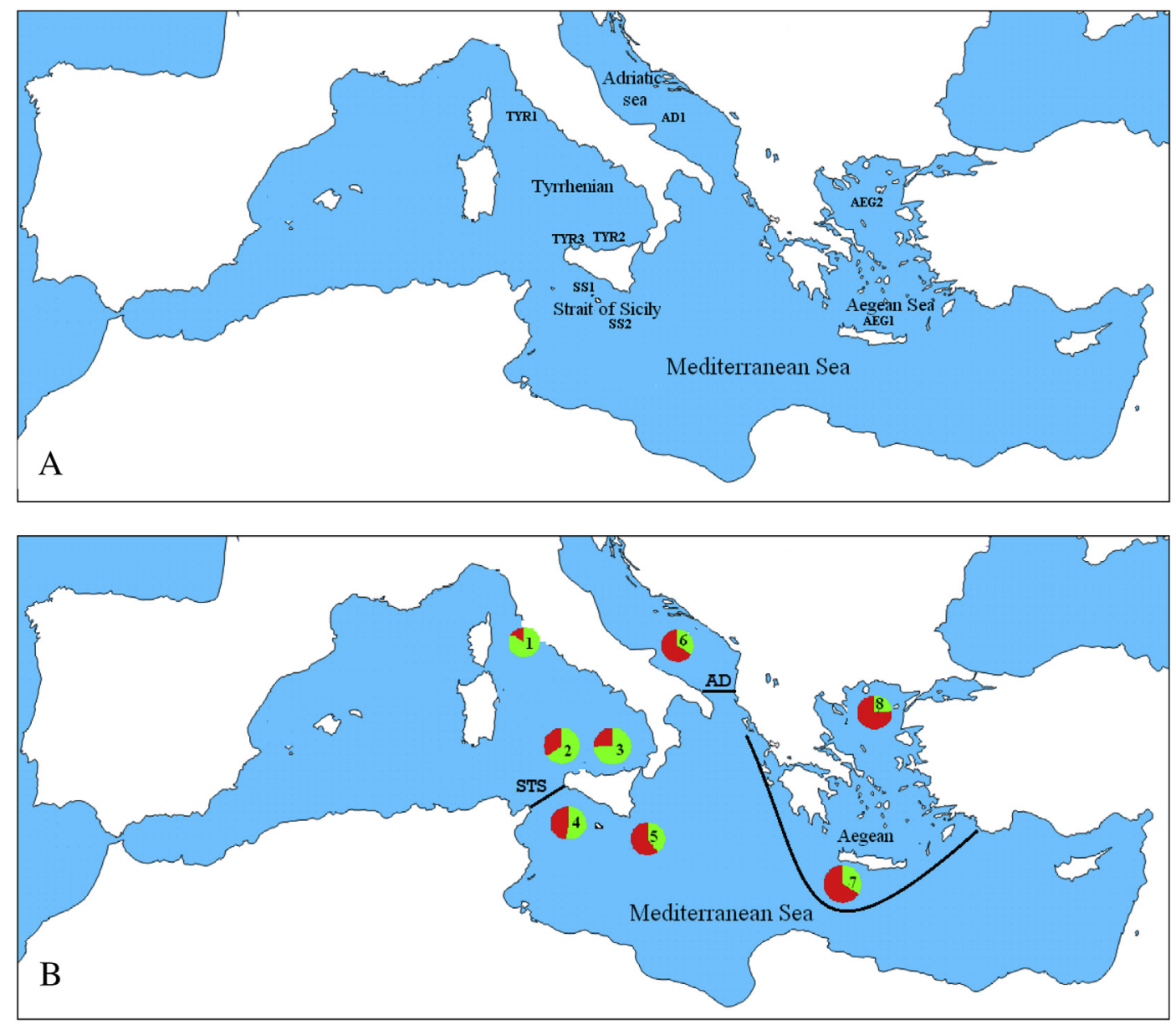

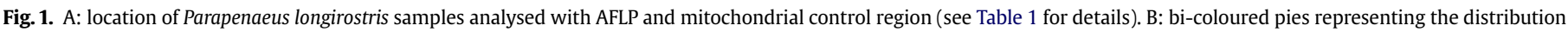

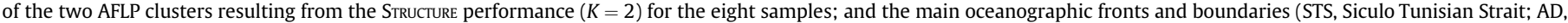
Adriatic barrier; Aegean or 'Levantine isolation') affecting genetic pattern of the deep-water rose shrimp.

their geographic location. This analysis permitted us to verify the partitioning of genetic variation among-populations on the whole, without the design of groups of populations, and a upper hierarchical level of groups of populations. Within and among the groups generated the following partition of diversity: $\Phi_{\mathrm{ST}}$, (the average within-populations diversity within groups), $\Phi_{\mathrm{SC}}$ (the average among-populations diversity within groups) and $\Phi_{\mathrm{CT}}$ (amonggroups). Population relationships were also investigated by building a UPGMA (Unweighted Pair Group Method with Arithmetic mean) tree with MEGA 4 (Tamura et al., 2007), based on Nei's genetic distance, as calculated in AfLP-SuRv, and topological confidence was evaluated with 1000 bootstrap replicates.

The values for pairwise Reynolds genetic distances, as calculated in AfLP-SuRv, were plotted against geographical distances, under the null hypothesis of a one-dimensional stepping-stone model. The strength and significance of this relationship were tested by Mantel's permutation test (Mantel, 1967), on a ARLEQUIN platform. Geographic distances between sampling sites were calculated as the shortest water-way along the $200 \mathrm{~m}$ bathymetric line.

Population differentiation was also inferred using a Bayesian approach, as implemented by STRUCTURE (Pritchard et al., 2000). This software was used to examine the most likely number of distinct genetic clusters $(K)$, assigning individuals to populations and to identify migrants and admixed individuals. Ten replicates for every value of $K$ were performed, with $K$ ranging from 1 to 8 (burn-in length 100,000). The true number of genetic clusters, $K$, is commonly identified as that with the highest posterior probability $(P(X \mid K))$, but since an increase in the probability values could lead to an overestimation of the number of genetic clusters, the procedure suggested by Evanno et al. (2005) was used to search for the lowest number of $\mathrm{K}$ based on the second order rate of variation of $\ln P(D)$. Delta $(K)$ is the mean of the second order rate of change of the $\ln P(D)$ values of a given $K$ divided by the $\ln P(D)$ standard deviation.

\section{3. mtDNA analysis}

The putative mitochondrial non-coding control region was amplified by using Ile-3 and $12 \mathrm{~S}-2$ primers (Chu et al., 2003). PCR was carried out in a Perkin Elmer Cetus Thermal cycler in a $25 \mu \mathrm{l}$ solution containing $1 \mathrm{ng}$ genomic DNA, $0.2 \mu \mathrm{M}$ each dNTPs, $0.1 \mu \mathrm{M}$ each primer, buffer $10 \times$ containing $10 \mathrm{mM}$ Tris $-\mathrm{HCl}(\mathrm{pH}$ 9), $50 \mathrm{mM}$ $\mathrm{KCl}, 1.5 \mathrm{mM} \mathrm{MgCl} 2$ and 2.5 units of Perkin Elmer Taq polymerase. The thermal cycling profile began at $94^{\circ} \mathrm{C}$ for $3 \mathrm{~min}$ as a hot start, followed by 5 cycles of $94^{\circ} \mathrm{C}(60 \mathrm{~s}), 48^{\circ} \mathrm{C}(45 \mathrm{~s})$ and $72{ }^{\circ} \mathrm{C}(60 \mathrm{~s}), 35$ subsequent cycles of $94{ }^{\circ} \mathrm{C}(60 \mathrm{~s}), 52{ }^{\circ} \mathrm{C}(45 \mathrm{~s})$ and $72{ }^{\circ} \mathrm{C}(60 \mathrm{~s})$, with a final step of $10 \mathrm{~min}$ at $72{ }^{\circ} \mathrm{C}$ for the termination of PCR. PCR products were separated on a $2 \%$ agarose gel which had been stained with ethidium bromide. Thereafter, they were purified using a Qiaquick PCR purification Kit and sequenced on an ABI Prism 310 automated sequencer (Applied Biosystems). The sequences were aligned using CLUSTAL X (Thompson et al., 1997) on a 
default setting and thereafter the sequence alignment was visually rechecked. The data were analysed for estimating intra-population diversity, including nucleotide $(\pi)$ and haplotype $(h)$ diversity. Statistical data analyses were conducted using DNASP 4.10 (Rozas et al., 2003), MEGA 4 and ARLEQUIN 3.0 softwares.

The overall genetic differentiation among samples was computed by AMOVA as described above. Pairwise $\Phi_{\mathrm{ST}}$ values were calculated to test genetic differentiation between each sample by using ARLeQuin 3.0, and the sequential Bonferroni test (Rice, 1989) was used to test significance. The pairwise values of $F_{\mathrm{ST}} /\left(1-F_{\mathrm{ST}}\right)$ were then plotted against geographical distances (one-dimensional stepping-stone model) to verify the Isolation By Distance (IBD) model (Slatkin, 1993). The null hypothesis of no correlation between genetic differentiation and geographic distances was tested by applying the Mantel permutation test. A UPGMA dendrogram illustrating the pattern of differentiation among samples was constructed, using Reynolds Distance by applying the method implemented in the MEGA software.

\section{Results}

\subsection{AFLP results}

The three primer combinations yielded a total of 143 polymorphic loci in the 240 analysed specimens from 8 populations. The proportion of polymorphic loci across the populations ranged from $45 \%$ to $95 \%$. Total gene diversity, $H_{\mathrm{T}}$ was 0.291 and the withinpopulation Nei's gene diversity, $H_{\mathrm{E}}$, ranged from 0.175 (AD1) to 0.325 (TYR1).

The hierarchical AMOVA was conducted on the neutral dataset excluding the detected outlier and clustering the samples in different ways in order to define the distribution of genetic variation. In the first clustering (i.e. all together) the highest proportion of genetic variation was found within-population and a significant value of $\Phi_{\mathrm{ST}}$ was reported (Table 2 ). When the samples were clustered into four groups (analysis $2 \mathrm{AFLP}$ ), according to their location in the Mediterranean sub basins (TYR + SS + AD + AEG), the greater portion of genetic variation was always within-populations (79.53\%) and the among-groups fixation index proved to be significantly different from zero $\left(\Phi_{\mathrm{CT}}=0.118\right.$; $\left.p<0.001\right)$. Subsequently, the exclusion of the AEG samples (analysis $3_{\mathrm{AFLP}}$ ) resulted in the reduction of the among-groups fixation index $\left(\Phi_{\mathrm{CT}}=-0.001\right.$; N.S.); the same result was obtained in the Analysis $4_{\mathrm{AFLP}}$ in which the TYR samples were excluded $\left(\Phi_{\mathrm{CT}}=-0.001\right.$; N.S.). The results of Analysis $3 \mathrm{AFLP}$ and $4_{\mathrm{AFLP}}$ indicated that the greatest contribution to the differences among the four Mediterranean sub basins depended on the Aegean (AEG) and Tyrrhenian (TYR) areas, which represented the most divergent groups.

The UPGMA tree revealed the deep separation of the Aegean samples (AEG) from the remaining populations (Fig. 2). The Mantel's test, applied to the relationship between genetic vs. geographical distances, indicated a significant relationship $(p=0.007, r=0.88)$ and thus supporting an Isolation By Distance model (Fig. 3). The strongest differentiation occurred between the most distant samples (TYR1-2 and AEG1-2) and the remaining samples fitted a clinal distribution of the gene pool.

The Bayesian analysis implemented in STRUCTURE yielded the highest value for posterior probability for $K=8$, indicating the presence of a substructure among $P$. longirostris samples. The $\Delta K$ vs $K$ curve indicated most support for $K=2$. In accordance with this model, the specimens from TYR were strongly assigned to the first cluster, and the samples from SS and AD were scattered more or less randomly to the two clusters, with the AEG samples being primarily assigned to the second cluster (Fig. 4).

Table 2

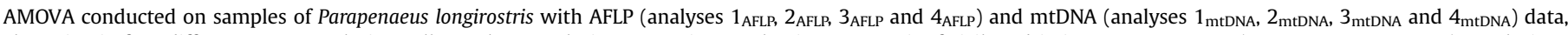

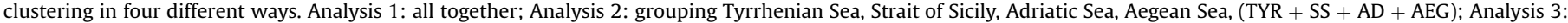

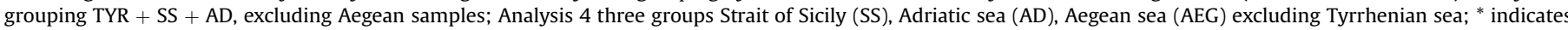
$p<0.05$ and ${ }^{* *} p<0.001$.

\begin{tabular}{|c|c|c|c|c|c|}
\hline & Sample clustering & Variation source & $\begin{array}{l}\text { Degrees of } \\
\text { freedom }\end{array}$ & $\begin{array}{l}\text { Variation } \\
(\%)\end{array}$ & $\begin{array}{l}\text { Fixation } \\
\text { indices }\end{array}$ \\
\hline \multirow[t]{2}{*}{$1_{\mathrm{AFLP}}$} & All together & Among-populations & 7 & 18.5 & $\Phi_{\mathrm{ST}} 0.185^{* *}$ \\
\hline & & Within-populations & 125 & 81.5 & \\
\hline \multirow[t]{3}{*}{2 AFLP } & Four groups: & Among-groups & 3 & 11.78 & $\Phi_{\mathrm{CT}} 0.118^{* *}$ \\
\hline & $\mathrm{TYR}+\mathrm{SS}+\mathrm{AD}+\mathrm{AEG}$ & $\begin{array}{l}\text { Among-populations } \\
\text { within groups }\end{array}$ & 4 & 8.69 & $\Phi_{\mathrm{SC}} 0.098^{* *}$ \\
\hline & & Within-populations & 125 & 79.53 & $\Phi_{\mathrm{ST}} 0.204^{* *}$ \\
\hline \multirow[t]{3}{*}{$3_{\mathrm{AFLP}}$} & Three groups: & Among-groups & 2 & -0.08 & $\Phi_{\mathrm{CT}}-0.001$ \\
\hline & $\mathrm{TYR}+\mathrm{SS}+\mathrm{AD}$ & $\begin{array}{l}\text { Among-populations } \\
\text { within groups }\end{array}$ & 3 & 14.02 & $\Phi_{\mathrm{SC}} 0.140^{*}$ \\
\hline & & Within-populations & 67 & 86.06 & $\Phi_{\mathrm{ST}} 0.139^{*}$ \\
\hline \multirow[t]{3}{*}{$4_{\mathrm{AFLP}}$} & Three groups: & Among-groups & 2 & 7.25 & $\Phi_{\mathrm{CT}} 0.090$ \\
\hline & $\mathrm{SS}+\mathrm{AD}+\mathrm{AEG}$ & $\begin{array}{l}\text { Among-populations } \\
\text { within groups }\end{array}$ & 2 & 20.76 & $\Phi_{\mathrm{SC}} 0.207^{*}$ \\
\hline & & Within-populations & 57 & 71.99 & $\Phi_{\mathrm{ST}} 0.280^{*}$ \\
\hline \multirow[t]{2}{*}{$1_{\mathrm{mtDNA}}$} & All together & Among-populations & 7 & 5.10 & $\Phi_{\mathrm{ST}} 0.051^{* *}$ \\
\hline & & Within-populations & 99 & 94.90 & \\
\hline \multirow[t]{3}{*}{$2 \mathrm{mtDNA}$} & Four groups: & Among-groups & 3 & 4.12 & $\Phi_{\mathrm{CT}} 0.046^{*}$ \\
\hline & $\mathrm{TYR}+\mathrm{SS}+\mathrm{AD}+\mathrm{AEG}$ & $\begin{array}{l}\text { Among-populations } \\
\text { within groups }\end{array}$ & 4 & 1.76 & $\Phi_{\mathrm{SC}} 0.022^{*}$ \\
\hline & & Within-populations & 100 & 94.12 & $\Phi_{\mathrm{ST}} 0.058^{* *}$ \\
\hline \multirow[t]{3}{*}{$3 \mathrm{mtDNA}$} & Three groups: & Among-groups & 2 & -0.51 & $\Phi_{\mathrm{CT}}-0.005$ \\
\hline & $\mathrm{TYR}+\mathrm{SS}+\mathrm{AD}$ & $\begin{array}{l}\text { Among-populations } \\
\text { within groups }\end{array}$ & 3 & 0.99 & $\Phi_{\mathrm{SC}} 0.009$ \\
\hline & & Within-populations & 86 & 99.52 & $\Phi_{\mathrm{ST}} 0.005$ \\
\hline \multirow[t]{3}{*}{$4_{\mathrm{mtDNA}}$} & Three groups: & Among-groups & 2 & 0.42 & $\Phi_{\mathrm{CT}} 0.004$ \\
\hline & $\mathrm{SS}+\mathrm{AD}+\mathrm{AEG}$ & $\begin{array}{l}\text { Among-populations } \\
\text { within groups }\end{array}$ & 2 & 0.95 & $\Phi_{\mathrm{SC}} 0.009$ \\
\hline & & Within-populations & 57 & 98.63 & $\Phi_{\mathrm{ST}} 0.013^{*}$ \\
\hline
\end{tabular}




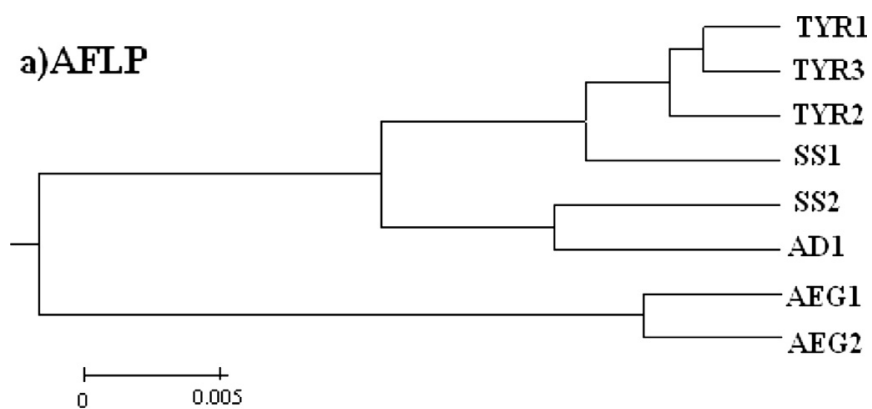

\section{b) mtDNA}

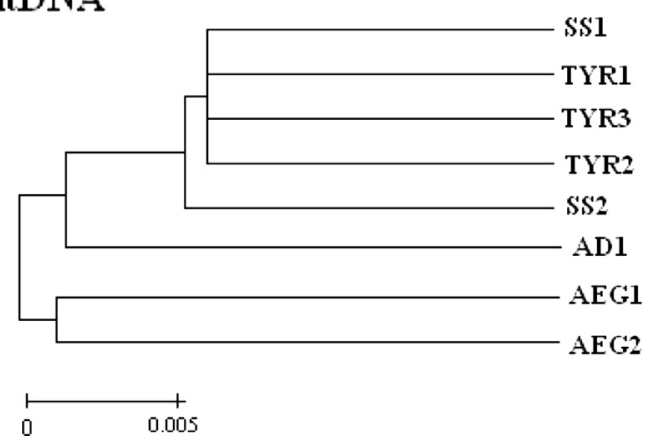

Fig. 2. UPGMA dendrograms based on Nei's genetic distance for AFLP (a) and on Reynolds distance for mtDNA (b). The scale bars represent the genetic distance.

\section{2. $m t D N A$ results}

The 307 bp fragment revealed 77 different haplotypes among 107 analyzed specimens, of which only 8 were shared among different individuals and the remaining 69 were unique. The shared
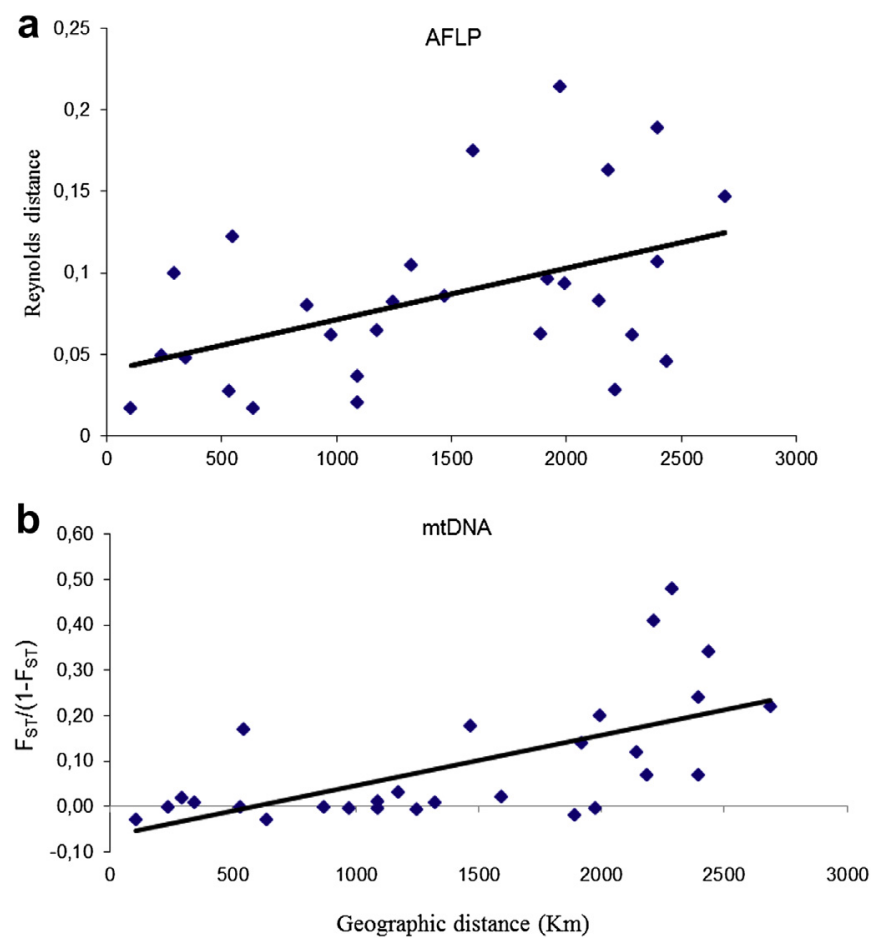

Fig. 3. Relationship between genetic vs. geographical distances showing an Isolation By Distance (IBD) pattern for AFLP (a) and mtDNA (b) data. Genetic differentiation was computed as Reynolds distance for AFLP and as $F_{\mathrm{ST}} /\left(1-F_{\mathrm{ST}}\right)$ for mtDNA and plotted against geographic distance in $\mathrm{Km}$. Lines represent the regression lines over all pairwise comparisons.

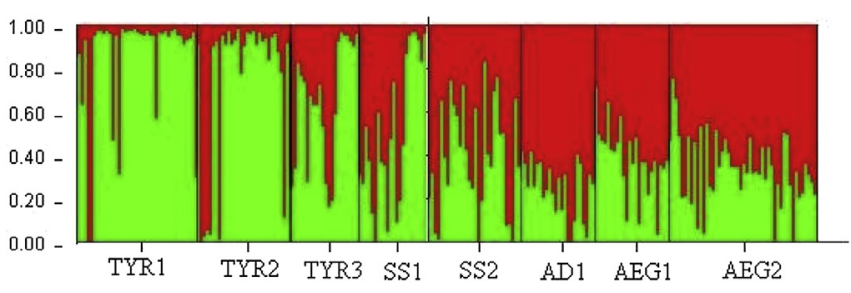

Fig. 4. Bayesian assignment analysis for $K=2$. Each bar represents an individual of Parapenaeus longirostris and its associated probability of belonging to one of the two genetic clusters detected (green and red). (For interpretation of the references to colour in this figure legend, the reader is referred to the web version of this article.)

haplotypes frequency ranged from 0.018 to 0.159 ; the 77 haplotypes differed from one another by 1-51 mutations. The most frequent haplotype was common to all the samples excluding from AEG. Haplotype diversity $(h)$ within populations was high, ranging from 1 (in TYR1, AD1, AEG1 and AEG2) to 0.867 (TYR2). Nucleotide diversity $(\pi)$ was low, ranging from 0.022 (TYR3) to 0.054 (AD1) (Table 3).

The hypothesis of panmixia among Mediterranean populations was rejected with the high statistical significance from the AMOVA analyses. Indeed, the all together and four groups analysis reported a significant value for the fixation indices (Analysis $1 \mathrm{mtDNA}$ $\Phi_{\mathrm{ST}}=0.051 ; p<0.001$; Analysis $\left.2_{\mathrm{mtDNA}} \Phi_{\mathrm{CT}}=0.046 ; p<0.001\right)$. As reported in AFLP results, when the AEG and the TYR group were excluded from the analysis (Analysis 3 mtDNA and Analysis 4 mtDNA, respectively; Table 2) no indication of an among-groups structure was found and the fixation index was not significantly different from zero. Pairwise $\Phi_{\mathrm{ST}}$ values were also reported (Table 4) and, again the two Aegean populations (AEG1 and AEG2) differed significantly from all the others. A Mantel test revealed a significant correlation between $F_{\mathrm{ST}} /\left(1-F_{\mathrm{ST}}\right)$ and geographic distances $(r=0.85 ; p=0.005)$, indicating an Isolation By Distance pattern among the populations of $P$. longirostris from central to eastern Mediterranean Sea, similarly in the mitochondrial dataset (Fig. 3). The UPGMA tree constructed with the Reynolds distance is shown in Fig. 2, which confirms a clear geographic partitioning of genetic distance with AEG and TYR samples as being the most divergent, though TYR forms a polytomy with the samples from SS.

\section{Discussion}

This study provides the first data regarding the genetic structure of the deep-water rose shrimp $P$. longirostris in the central and eastern Mediterranean Sea, using nuclear and mitochondrial markers.

AFLP and mitochondrial control region revealed concordant results. The markers rejected the null hypothesis of panmixia in favour of a heterogeneous distribution of the genotypes and haplotypes. Results of the genetic distances and assignment methods

Table 3

Genetic diversity of the mitochondrial control region of Parapenaeus longirostris.

\begin{tabular}{llll}
\hline Sample & Haplotypes & $h$ & $\pi$ \\
\hline TYR1 & 14 & 1.000 & 0.034 \\
TYR2 & 11 & 0.882 & 0.024 \\
TYR3 & 11 & 0.933 & 0.022 \\
SS1 & 14 & 0.971 & 0.046 \\
SS2 & 11 & 0.956 & 0.027 \\
AD1 & 15 & 1.000 & 0.054 \\
AEG1 & 6 & 1.000 & 0.040 \\
AEG2 & 9 & 1.000 & 0.039 \\
\hline
\end{tabular}

$h$, haplotypic diversity; $\pi$, nucleotidic diversity. 
Table 4

Pairwise $\Phi_{\mathrm{ST}}$ values, based on the mitochondrial control region sequences of samples of Parapenaeus longirostris.

\begin{tabular}{lllllllll}
\hline \multicolumn{1}{c}{ TYR1 } & TYR2 & TYR3 & SS1 & SS2 & AD1 & AEG1 & AEG2 \\
\hline TYR1 & - & & & & & & & \\
TYR2 & -0.005 & & & & & & & \\
TYR3 & -0.001 & -0.029 & & & & & & \\
SS1 & 0.011 & -0.002 & 0.008 & & & & & \\
SS2 & -0.003 & -0.018 & -0.030 & 0.018 & & & & \\
AD1 & -0.004 & 0.009 & -0.007 & 0.020 & -0.019 & & & \\
AEG1 & $0.068^{*}$ & $0.168^{* *}$ & $0.121^{*}$ & $0.068^{*}$ & $0.107^{*}$ & 0.032 & & \\
AEG2 & $0.184^{* *}$ & $0.324^{* *}$ & $0.290^{* *}$ & $0.193^{* *}$ & $0.252^{* *}$ & $0.146^{* *}$ & $0.144^{*}-$ \\
\hline
\end{tabular}

${ }^{*} p<0.05$ and ${ }^{* *} p<0.001$.

assessed a significant and gradual differentiation from the Tyrrhenian (TYR), Adriatic (AD), Strait of Sicily (SS), to the Aegean (AEG) area, describing an Isolation By Distance (IBD) model. This was evidenced by a positive correlation between the genetic and geographic distance (Fig. 3) along an ideal west-east axis (Fig. 1). The Bayesian analysis (Fig. 4), with the two hypothesized genetic clusters $(K=2)$, showed a clinal population structuring over a large range in which the nearest sampling areas were the most genetically similar, and the proportion of membership of the individuals to the two identified genetic clusters increased/decreased from west to east and vice versa.

The clinal, genetic variation of the deep-water rose shrimp shares similarities with other marine species in the Mediterranean Sea (De Matthaeis et al., 2000; Diaz-Almela et al., 2004; Vias et al., 2004; Pérez-Losada et al., 2007; Zulliger et al., 2009; Babbucci et al., 2010). In all these studies it is evident as the genetic differentiation is not sharp and does not show breakpoints due to well-defined physical barriers to gene flow but rather it arises as geographic distance increases.

As commonly observed in marine realm, such clinal variation is often detected on a wide geographical range, as the example of the European anchovy Engraulis encrasicolus, which exhibited an IBD pattern among the NE Atlantic samples from the Bay of Biscay to the Canary Islands, including the Alboran Sea (Zarraonaindia et al., 2012). Over long distances the role of hydrodynamic factors, such as currents, water fronts, eddies, is crucial.

Particularly in the Mediterranean sea, there are various potential physical barriers to individual displacements, mostly placed in the Siculo-Tunisian Strait (STS) (Fig. 1) (e.g. Mejri et al., 2009) and at the boundaries of the Adriatic sub-basin and the Aegean region (Fig. 1) (e.g. Maggio et al., 2009b; Mejri et al., 2011).

The IBD pattern describes at the same time a some homogeneity within the total meta-population, and heterogeneity among subgroups, detected at both side of important oceanographic transition zones. Such contradiction, homogeneity on the whole and heterogeneity spatially confined, is not uncommon, and several authors proved it (e.g. Zarraonaindia et al., 2012; Babbucci et al., 2010).

The Strait of Sicily represents a nursery and spawning area (Fortibuoni et al., 2010) and one of the most important fishing grounds for Mediterranean trawlers targeting P. longirostris (Levi et al., 1995; Abelló et al., 2002; Sobrino et al., 2005), and is characterised by a complex hydrodynamic system (Béranger et al., 2004). It is influenced principally by two main fluxes: the Atlantic Ionian Stream (AIS) from west to east, and the Levantine Intermediate Water (LIW) flowing in the opposite direction. Both are coupled with vortexes and fronts, such as the Adventure Bank Vortex (ABV), the Ionian Shelf-break Vortex (ISV), and the Ionian Slope Front (ISF) (Astraldi et al., 2002; Millot and Taupier-Letage, 2005).

According to Agostini and Bakun (2002), the Strait of Sicily shows the ocean triad conditions, which generate eggs and larvae retention. Enrichment processes, such as upwelling, mixing, cyclonic eddy formation, enhance food availability for predators through increasing the concentration of food particles, and contribute towards keeping individual members of a population in the appropriate place during the various parts of the life cycle.

The Atlantic Water (AW) flowing eastwards produces mesoscale eddies (Hamad et al., 2006) which further isolate the Aegean subbasin. Thus, a turbulent regime which prevents a passive and plentiful displacement of individuals from the Tyrrhenian area through the Strait of Sicily towards the Adriatic and the Aegean, and vice versa, occurs.

In general, an IBD pattern can be characterized by different degrees of genetic discontinuities. The degree of genetic discontinuity can be different along the cline, so that a group of neighbouring populations can result much more differentiated than the rest of the group. In the light of such hypothesis, it cannot be excluded that the eastern $P$. longirostris populations are more differentiated from the others ('Levantine isolation'), though unsampled populations (ghost populations) may have obscured important information.

According to the present results, the deepest discrepancy in the genetic population structure has been observed between the Aegean samples and the others (shown in dendrograms of Fig. 2), highlighting a 'Levantin isolation' which characterizes the eastern Mediterranean basin. Hydrodynamic and ecological conditions of this Mediterranean region affect the distribution of genotypes. The Aegean sub-basin has been supposed to preserve genetically different populations within many species (e.g. Mejri et al., 2011; Borrero-Pérez et al., 2011), even in good swimmer fishes, for instance the sea bass Dicentrarchus labrax as reported by Castilho and Ciftci (2005).

In the case of $P$. longirostris, such hydrodynamic forces do not sufficiently act to prevent isolated demes, while long-distance dispersal is not durable enough to guarantee homogenization.

Other than the oceanographic barriers, the IBD pattern may reflect the dispersal of specific phenotypes/genotypes and it can be of biological significance. Indeed the genetic architecture has been demonstrated to be related to life history traits (Vias et al., 2004; Bradbury and Bentzen, 2007; García-Merchán et al., 2012).

The mortality of long-distance shrimp dispersers in concert with complex circulation can reduce the effective dispersal commonly associated with the pelagic larval period. However, the gene flow pattern cannot depend only on the passive larval dispersion but it can also be guaranteed by the active displacement of adults. The mobility of $P$. longirostris adults is considered to be high (Levi et al., 1995) although comprehensive studies are lacking. Adult migrations primarily depend on trophic resources; and, temperature values $\left(<16{ }^{\circ} \mathrm{C}\right)$ are also considered a limiting factor regarding the distribution of the species (Tom et al., 1988; Ungaro and Gramolini, 2006).

The present dataset concurs to better design the genetic structure of $P$. longirostris; and integrates results by García-Merchán et al. (2012). They did not find heterogeneity among the P. longirostris samples at both sides of the oceanographic discontinuity area separating Atlantic and Mediterranean, most likely due to the restricted geographic sampling area. The characteristics of the Gibraltar Strait area, where fronts and eddies strongly influence the water circulation, could render the area suitable for the mixing of the pelagic and bentho-pelagic stadium of crustaceans. The transition Atlantic - Mediterranean area cannot be considered as a physical barrier to gene flow within some species, but rather an area in which the adults and the juveniles can mix horizontally and vertically along the water column in relation to the availability of trophic resources. Such proposition can be attributed to the ocean triad conditions likewise detected in the Alboran Sea by Agostini and Bakun (2002). 
Many factors concur in depicting the various genetic patterns, locally and on a large spatial scale, and further studies needs characterizing the dispersal ability of the species. Of note is the importance of studying deep-water species in the Mediterranean Sea, where data linked to oceanographic features, trophic availability and ecological conditions could provide us with much more information relating to this scarcely known ecosystem, as also reported by several authors (Company et al., 2008; Nouar et al., 2011; García-Merchán et al., 2012).

\section{Acknowledgements}

The authors are grateful to Prof. G. Kotoulas, Prof. A Kallianiotis and Prof. F. Tinti for collecting samples of Parapenaeus longirotris from Greek and Adriatic coasts. They would also thank Dr F. Garoia for much appreciated laboratory support. This research was partially supported by "Fondi d'Ateneo ex 60\%" and POR-Sicilia No. 0062. A great appreciation for the language correction by Jane $\mathrm{O}$. Davies. The authors are grateful to the anonymous reviewers which provided valuable suggestions and comments during revision of the manuscript.

\section{References}

Abdel Razek, F.A., El-Sherief, S.S., Taha, S.M., Muhamad, E.G., 2006. Some biological studies of Parapenaeus longirostris (Lucas, 1846) (Crustacea, Decapoda) in the Mediterranean coast of Egypt. Egyptian Journal of Aquatic Research 32, 385400.

Abelló, P., Abella, A., Adamidou, A., Jukic-Peladic, S., Maiorano, P., Spedicato, M.T., 2002. Geographical patterns in abundance and population structure of Nephrops norvegicus and Parapenaeus longirostris (Crustacea: Decapoda) along the European Mediterranean coasts. Scientia Marina 66, 125-141.

Agostini, V.N., Bakun, A., 2002. 'Ocean triads' in the Mediterranean Sea: physical mechanisms potentially structuring reproductive habitat suitability (with example application to European anchovy, Engraulis encrasicolus). Fisheries Oceanography $11,129-142$.

Arculeo, M., 2009. Dati di sbarco e biologia del gambero rosa Parapenaeus longirostris (Lucas, 1846) (Crustacea Penaeidae) nella Sicilia nord occidentale. Naturalista Siciliano IV, 253-266.

Ardizzone, G.D., Gravina, M.F., Belluscio, A., Schintu, P., 1990. Depth-size distribution pattern of Parapenaeus longirostris (Lucas, 1846) (Decapoda) in the central Mediterranean sea. Journal of Crustacean Biology 10, 139-147.

Astraldi, M., Gasparini, G.P., Vetrano, A., Vignudelli, S., 2002. Hydrographic characteristics and interannual variability of water masses in the central Mediterranean: a sensitivity test for long-term changes in the Mediterranean Sea. Deep Sea Research Part I 49, 661-680.

Aydın, C., Tosunoğlu, Z., 2012. Evaluation of sorting grids for deepwater rose shrimp (Parapenaeus longirostris) in the Eastern Mediterranean demersal trawl fishery. Journal of Applied Ichthyology 28, 102-106.

Babbucci, M., Buccoli, S., Cau, A., Cannas, R., Goñi, R., Díaz, D., Marcato, S., Zane, L., Patarnello, T., 2010. Population structure, demographic history, and selective processes: contrasting evidences from mitochondrial and nuclear markers in the European spiny lobster Palinurus elephas (Fabricius, 1787). Molecular Phylogenetics and Evolution 56, 1040-1050.

Bayhan, Y.K., Ünlüer, T., Akkaya, M., 2005. Some biological aspects of Parapenaeus longirostris (Lucas, 1846) (Crustacea, Decapoda) inhabiting the Sea of Marmara. Turkish Journal of Veterinary and Animal Sciences 29, 853-856.

Beaumont, M.A., Nichols, R.A., 1996. Evaluating loci for use in the genetic analysis of population structure. Proceedings of the Royal Society of London Series B 263, 1619-1626.

Beaumont, M.A., Balding, D.J., 2004. Identifying adaptive genetic divergence among populations from genome scans. Molecular Ecology 13, 969-980.

Béranger, K., Mortier, L., Gasparini, G.P., Gervasio, L., Astraldi, M., Crépon, M., 2004 The dynamics of the Sicily Strait: a comprehensive study from observations and models. Deep-sea Research Part II 51, 411-440.

Bilgin, S., Ozen, O., Ismen, A., Ozekinci, U., 2009. Bathymetric distribution, seasonal growth and mortality of the deep-water rose shrimp Parapenaeus longirostris (Decapoda: Penaeidae) in an unexploited stock in Saros Bay, Aegean Sea. Journal of Animal and Veterinary Advances 8, 2404-2417.

Bombace, G., 1975. Considerazioni sulla distribuzione delle popolazioni di livello batiale con particolare riferimento a quelle bento-nectoniche. Pubblicazioni della Stazione Zoologica di Napoli 39, 7-21.

Borrero-Pérez, G.H., Gonzalez-Wanguemert, M., Marcos, C., Pérez-Ruzafa, A., 2011. Phylogeography of the Atlanto-Mediterranean sea cucumber Holothuria (Holothuria) mammata: the combined effects of historical processes and current oceanographical pattern. Molecular Ecology 20, 1964-1975.
Bradbury, I.R., Bentzen, P., 2007. Non-linear genetic isolation by distance: implications for dispersal estimation in anadromous and marine fish populations. Marine Ecology Progress Series 340, 245-257.

Caballero, A., Quesada, H., Rolán-Alvarez, E., 2008. Impact of AFLP fragment size homoplasy on the estimation of population genetic diversity and the detection of selective loci. Genetics 179, 539-554.

Cartes, J.E., 1995. Diets of, and trophic resources exploited by, bathyal penaeoidean shrimps from the western Mediterranean. Marine and Freshwater Research 46, 889-896.

Castilho, R., Ciftci, Y., 2005. Genetic differentiation between close eastern Mediterranean Dicentrarchus labrax (L.) populations. Journal of Fish Biology 67, 1746-1752.

Chu, K.H., Li, C.P., Tam, Y.K., Lavery, S., 2003. Application of mitochondrial control region in population genetic studies of the shrimp Penaeus. Molecular Ecology Notes 3, 120-122.

Colloca, F., Carpentieri, P., Balestri, E., Ardizzone, G.D., 2004. A critical habitat for Mediterranean fish resources: shelf-break areas with Leptometra phalangium (Echinodermata: Crinoidea). Marine Biology 145, 1129-1142.

Company, J.B., Puig, P., Sardà, F., Palanques, A., Latasa, M., Sharek, R., 2008. Climate influence on deep sea populations. PLoS One 3, e1431.

De Matthaeis, E., Davolos, D., Cobolli, M., Ketmaier, V., 2000. Isolation by distance in equilibrium and non equilibrium populations of four talitrid species in the Mediterranean Sea. Evolution 54, 1606-1613.

Dereli, H., Erdem, M., 2011. Spawning period and first maturity size of deep water rose shrimp (Parapenaeus longirostris) in the Aegean Sea. African Journal of Biotechnology 10, 15407-15415.

Diaz-Almela, E., Boudry, P., Launey, S., Bonhomme, F., Lapègue, S., 2004. Reduced female gene flow in the European flat oyster Ostrea edulis. Journal of Heredity 95, 510-516.

Dos Santos, A., 1998. On the occurrence of larvae of Parapenaeus longirostris (Crustacea: Decapoda: Penaeoidea) off the Portuguese coast. Journal of Natural History 32, 1519-1523.

Evanno, G., Regnaut, S., Goudet, J., 2005. Detecting the number of clusters of individuals using the software structure: a simulation study. Molecular Ecology 14, 2611-2620.

Excoffier, L., Laval, G., Schneider, S., 2005. Arlequin vers 3.0: and integrated software package for population genetic data analysis. Evolutionary Bioinformatics Online $1,47-50$.

Fortibuoni, T., Bahri, T., Camilleri, M., Garofalo, G., Gristina, M., Fiorentino, F., 2010. Nursery and spawning areas of deep-water rose shrimp, Parapenaeus longirostris (Decapoda: Penaeidae), in the Strait of Sicily (Central Mediterranean Sea). Journal of Crustacean Biology 30, 167-174.

Froglia, C., 1982. Contribution to the knowledge of the biology of Parapenaeus longirostris (Lucas) (Decapoda, Penaeoidea). Quaderni Laboratorio di Tecnologia della Pesca 3, 163-168.

García-Merchán, V.H., Robainas-Barcia, A., Abelló, P., Macpherson, E., Palero, F., García-Rodríguez, M., Gil de Sola, L., Pascual, M., 2012. Phylogeographic patterns of decapod crustaceans at the Atlantic-Mediterranean transition. Molecular Phylogenetics and Evolution 62, 664-672.

Guijarro, B., Massutí, E., Moranta, J., Cartes, J.E., 2009. Short spatio-temporal variations in the population dynamics and biology of the deep-water rose shrimp Parapenaeus longirostris (Decapoda: Crustacea) in the western Mediterranean. Scientia Marina 73, 183-197.

Hamad, N., Millot, C., Taupier-Letage, I., 2006. The surface circulation in the eastern basin of the Mediterranean Sea. Scientia Marina 70, 457-503.

Heldt, J.H., 1938. La reproduction chez les crustacés décapodes de la famille des pénéides. Annales de l'Institut Oceanographique. Fundation Albert I. Musée Oceanographique Monaco 18, 31-206.

Holthius, L.B., 1980. FAO Species Catalogue. Shrimps and Prawns of the World. In: An Annotated Catalogue of Species of Interest to Fisheries. FAO Fisheries Synopses 125, vol. 1. FAO, Italy, Rome.

Kapiris, K., 2004. Feeding ecology of Parapenaeus longirostris (Lucas, 1846) (Decapoda: Penaeidae) from the Ionian sea (Central and eastern Mediterranean sea). Scientia Marina 68, 247-256.

Lembo, G., Silecchia, T., Carbonara, P., Acrivulis, A., Spedicato, M.T., 1999. A geostatistical approach to the assessment of the spatial distribution of Parapenaeus longirostris (Lucas, 1846) in the central-southern Tyrrhenian Sea. Crustaceana 72, 1093-1108.

Lembo, G., Silecchia, T., Carbonara, P., Contegiacomo, M., Spedicato, M.T., 2000. Localization of nursery areas of Parapenaeus longirostris (Lucas, 1846) in the central-southern Tyrrhenian Sea by geostatistics. Crustaceana 73, 39-51.

Levi, D., Andreoli, M.G., Giusto, R.M., 1995. First assessment of the rose shrimp, Parapenaeus longirostris (Lucas, 1846) in the central Mediterranean. Fisheries Research 21, 375-393.

Ligas, A., Sartor, P., Colloca, F., 2011. Trends in population dynamics and fishery of Parapenaeus longirostris and Nephrops norvegicus in the Tyrrhenian Sea (NW Mediterranean): the relative importance of fishery and environmental variables. Marine Ecology 32, 25-35.

Lo Brutto, S., Maggio, T., Deiana, A.M., Cannas, R., Arculeo, M., 2012. Further investigation on population of the deep-water blue and red shrimp Aristeus antennatus (Risso, 1816) (Decapoda, Dendrobranchiata), as inferred from amplified length polymorphism (AFLP) and mtDNA analyses. Crustaceana 85 1393-1408.

Lynch, M., Milligan, B.G., 1994. Analysis of population genetic structure with RAPD markers. Molecular Ecology 3, 91-99. 
Maggio, T., Lo Brutto, S., Cannas, R., Deiana, A., Arculeo, M., 2009a. Environmental features of deep-sea habitats linked to the genetic population structure of a crustacean species in the Mediterranean Sea. Marine Ecology 30, 354-365.

Maggio, T., Lo Brutto, S., Garoia, F., Tinti, F., Arculeo, M., 2009b. Microsatellite analysis of red mullet Mullus barbatus (Perciformes, Mullidae) reveals the isolation of the Adriatic Basin in the Mediterranean Sea. ICES Journal of Marine Science 66, 1883-1891.

Mantel, N., 1967. The detection of disease clustering and a generalized regression approach. Cancer Research 27, 209-220.

Mejri, R., Lo Brutto, S., Ben Hassine, O.K., Arculeo, M., 2009. A study on Pomatoschistus tortonesei Miller 1968 (Perciformes, Gobiidae) reveals the SiculoTunisian Strait (STS) as a breakpoint to gene flow in the Mediterranean basin. Molecular Phylogenetics and Evolution 53, 596-601.

Mejri, R., Arculeo, M., Ben Hassine, O.K., Lo Brutto, S., 2011. Genetic architecture of the marbled goby Pomatoschistus marmoratus (Perciformes, Gobiidae) in the Mediterranean Sea. Molecular Phylogenetics and Evolution 58, 395-403.

Millot, C., Taupier-Letage, I., 2005. Additional evidence of LIW entrainment across the Algerian sub basin by mesoscale eddies and not by a permanent westward flow. Progress in Oceanography 66, 231-250.

Mori, M., Sbrana, M., De Ranieri, S., 2000. Reproductive biology of female Parapenaeus longirostris (Crustacea, Decapoda, Penaeidae) in the northern Tyrrhenian Sea (western Mediterranean). Atti della Società Toscana di Scienze Naturali Memorie Serie B 107, 1-6.

Nei, M., 1987. Molecular Evolutionary Genetics. Columbia University Press, New York.

Nouar, A., Kennouche, H., Ainoucheand, N., Cartes, J.E., 2011. Temporal changes in the diet of deep-water Penaeoidean shrimp (Parapenaeus longirostris and Aristeus antennatus) off Algeria (southwestern Mediterranean). Scientia Marina 75, 279-288.

Nouar, A., Maurin, C., 2001. Nature of and typical populations on the characteristic facies of substratum of Parapenaeus longirostris (Lucas, 1846) along the Algerian coast. Crustaceana 74, 129-135.

Pellerito, R., Bonhomme, F., Arculeo, M., 2009. Recent expansion of Northeast Atlantic and Mediterranean populations of Melicertus (Penaeus) kerathurus (Crustacea: Decapoda). Fisheries Sciences 75, 1089-1095.

Pérez-Losada, M., Nolte, M.J., Crandall, K.A., Shaw, P.W., 2007. Testing hypotheses of population structuring in the Northeast Atlantic Ocean and Mediterranean Sea using the common cuttle fish Sepia officinalis. Molecular Ecology 16, 2667-2679.

Pritchard, J.K., Stephens, M., Donnelly, P., 2000. Inference of population structure using multilocus genotype data. Genetics 155, 945-959.

Rice, W.R. 1989. Analyzing tables of statistical tests. Evolution 43, 223-225.

Rozas, J., Sánchez-Delbarrio, J.C., Messeguer, X., Rozas, R., 2003. DNAsp, DNA polymorphism analyses by the coalescent and other methods. Bioinformatics 19, 2496-2497.

Sbrana, M., Sartor, P., Belcari, P., 2003. Analysis of the factors affecting crustacean trawl fishery catch rates in the northern Tyrrhenian Sea (western Mediterranean). Fisheries Research 65, 271-284.
Sbrana, M., Viva, C., Belcari, P., 2006. Fishery of the deep-water rose shrimp Parapenaeus longirostris (Lucas, 1846) (Crustacea: Decapoda) in the northern Tyrrhenian Sea (western Mediterranean). Hydrobiologia 557, 135-144.

Slatkin, M., 1993. Isolation by distance in equilibrium and non-equilibrium populations. Evolution 47, 264-279.

Sobrino, I., Silva, C., Sbrana, M., Kapiris, K., 2005. A review of the biology and fisheries of the deep water rose shrimp, Parapenaeus longirostris, in European Atlantic and Mediterranean waters (Decapoda, Dendrobranchiata, Penaeidae). Crustaceana 78, 1153-1184.

Stamatis, C., Triantafyllidis, A., Moutou, K.A., Mamuris, Z., 2006. Allozymic variation in Northeast Atlantic and Mediterranean populations of Norway lobster Nephrops norvegicus. ICES Journal of Marine Science 63, 875-882.

Tamura, K., Dudley, J., Nei, M., Kumar, S., 2007. MEGA4: molecular Evolutionary genetics analysis (MEGA) software version 4.0. Molecular Biology and Evolution 24, 1596-1599.

Thompson, J.D., Gibson, T.J., Plewniak, F., Jeanmougin, F., Higgins, D.G., 1997. The CLUSTAL X Windows interface: flexible strategies for multiple sequence alignment aided by quality analysis tools. Nucleic Acids Research 25, 48764882.

Tom, M., Goren, M., Ovadia, M., 1988. The benthic phase of the life cycle of Parapenaeus longirostris (Crustacea, Decapoda, Penaeidae) along the Mediterranean coast of Israel. Hydrobiologia 169, 339-352.

Ungaro, N., Gramolini, R., 2006. Possible effect of bottom temperature on distribution of Parapenaeus longirostris (Lucas, 1846) in the southern Adriatic (Mediterranean Sea). Turkish Journal of Fisheries and Aquatic Sciences 6, 109116.

Vekemans, X., Beauwens, T., Lemaire, M., Roldan-Ruiz, I., 2002. Data from amplified fragment length polymorphism (AFLP) markers show indication of size homoplasy and a relationship between degree of homoplasy and fragment size. Molecular Ecology 11, 139-151.

Vias, J., Alvarado Bremer, J., Pla, C., 2004. Phylogeography of the Atlantic bonito (Sarda sarda) in the northern Mediterranean: the combined effects of historical vicariance, population expansion, secondary invasion, and isolation by distance. Molecular Phylogenetics and Evolution 33, 32-42.

Vos, P., Hogers, R., Bleeker, M., Reijans, M., van de Lee, T., Hornes, M., Frijters, A. Pot, J., Peleman, J., Kuiper, M., Zabeau, M., 1995. AFLP: a new technique for DNA fingerprinting. Nucleic Acids Research 23, 4407-4414.

Zarraonaindia, I., Iriondo, M., Albaina, A., Pardo, M.A., Manzano, C., Grant, W.S. Irigoien, X., Estonba, A., 2012. Multiple SNP markers reveal fine-scale population and deep phylogeographic structure in European anchovy (Engraulis encrasicolus L.). PLoS One 7, e42201.

Zhivotovsky, L.A., 1999. Estimating population structure in diploids with multilocus dominant DNA markers. Molecular Ecology 8, 907-913.

Zulliger, D.E., Tanner, S., Ruch, M., Ribi, G., 2009. Genetic structure of the high dispersal Atlanto-Mediterreanean sea star Astropecten aranciacus revealed by mitochondrial DNA sequences and microsatellite loci. Marine Biology 156, 597610. 